\title{
Implementing E-Assessment for Formative Test in Introduction of Education Course: Students' Voice
}

\author{
Eldarni \\ Universitas Negeri Padang, Indonesia \\ eldarni@fip.unp.ac.id \\ Fetri Yeni \\ Universitas Negeri Padang, Indonesia \\ eldarni@fip.unp.ac.id
}

\author{
Dedi Supendra \\ Universitas Negeri Padang, Indonesia \\ eldarni@ fip.unp.ac.id \\ Zuwirna \\ Universitas Negeri Padang, Indonesia \\ eldarni@fip.unp.ac.id
}

\begin{abstract}
Managing an effective procedure to assess the students' learning process has been a determining responsibility for lecturers to discover the comprehensive result. Regardless of the different mode of the test, such as multiple-choice questions, essay, true and false, etc., the lecturers seldom apply a paperless approach. This study aims to analyze the students' perspective on conducting an e-assessment for the formative test in the introduction of education course. This research applies descriptive qualitative methods and 5 students of introduction to education course involve in the interview session. From the collected data which has been analyzed with thematic analysis, it is found that the students are more comfortable to have the test using eassessment since they can answer the questions through their personal digital devices, such as laptop or handphone. In addition, seeing a list of questions on the paper makes them nervous and they do not have to feel bothering with the mark they should create to change the answer on the answer sheet. Besides, getting feedback immediately help them to improve their learning.
\end{abstract}

Keywords: e-assessment, electronical assessment, formative test, paperless test

\section{INTRODUCTION}

The government of Indonesia through the act of national education system No. 20 the year 2003 article 57 paragraph 1 states that there is a need for efforts to improve the quality of national education as a form of accountability of education providers to interested parties (Depdiknas, 2003). To manage the quality of education in the specific contextual setting such as schools, teachers have a significant role to measure students' learning results. Measurement of student learning outcomes requires an instrument that is used as a measure in collecting student learning outcomes data through examination. One of the test forms that has a strategic position in measuring students' learning success rates is formative tests.

Formative testing is one form of test that can function as a measure of the learning progress of students. The formative test is a test of learning outcomes that aims to find out, to what extent students have been formed, which is in accordance with the learning objectives that have been determined. Purwanto (2012) states that the purpose of a formative test is to seek feedback (feedback), which in turn can be used to improve the teaching and learning process that is being implemented or has been implemented. Formative tests are carried out in the midst of learning programs to monitor student learning progress and to determine the extent to which students "have formed", according to the learning objectives that have been set. Biggs (2003) stated that the formative test assists students to have a better understanding and engagement with the learning materials. However, the implementation of the learning outcomes test is still characterized by several obstacles, including a small number of students who commit cheating, such as viewing notes, seeing friends' answers, and other forms of cheating. Another problem is that the test is still applying paper-based testing.

The use of paper-based testing still has many weaknesses, including spending quite much budget to provide question and answer sheets. In addition, it is possible that there will be human error on marking students' answer manually. Besides that, it is also feared that it will have an impact on the lack of validity of the data obtained in the measurement process. This will also affect the decision making of the evaluation of learning outcomes that will be carried out by the teacher to improve the subsequent learning process. If the decision taken by the teacher in the evaluation process is not correct, then the improvement of learning done in the future will also be less targeted.

Therefore, digital technologies appear to help teachers assess students' learning process through electronic assessment (e-assessment). Many studies stated that e-assessment is all the assessment steps which involve digital tools from the beginning process of the test, such as designing the questions, distributing the questions, to giving feedback at the end.

E-assessment can be applied to various types of test, for example, online testing including multiple-choice questions and problem-solving questions which is delivered through web-based test equipment (Ridgway, McSucker, Pead, 2004; Sitthisak, Gilbert, Davis, 2008). According to Alruwais, Wills, and Wald (2017), eassessment is a better method to apply in universities to 
procure an accurate and faster learning result of students than the paper-based method.

From some of the explanation above regarding the benefits of e-assessment from a general perspective, it can be seen that this kind of online measurement has a positive influence on the development of learning system, especially in the evaluation phase. However, this condition should also cover another certain perspective, such as students. This research then aims to discover how students opine with having e-assessment to create amusing and meaningful learning process. It is because students with different backgrounds cannot be guaranteed to have the same argument on what they want to experience in the academical atmosphere. In this case, the teachers should have the ability to read the situation and do not insist the students do what they are not comfortable with.

\section{METHOD}

The qualitative analysis method was applied to answer the research question. This approach is suitable to collect a richer understanding of someone's perspective and to get more in-depth information (Norton, 2009, p.116). As a sampling, five students of the Introduction of Education course who are from the different program in Universitas Negeri Padang, West Sumatera, Indonesia were interviewed individually asked their experiences of conducting an electronic assessment. In a qualitative method, the sample size is not necessary to have as much as data quantitatively. But Mason (2010) stated that it must be large enough to assure that most or all the perceptions that might be important are uncovered.

In this study, thematic analysis applied to decode, analyse, interpret, and discuss the data collected started from doing initial reading for the whole of interview transcript to understand generally the answers of each participant and to find some common issues (Norton, 2009; Braun and Clark, 2006), such as learning experiences and environment in Universitas Negeri Padang, hobbies, lecturers, classmates and the different learning system between senior high school and university. Furthermore, it is conducted closer reading to see a more specific pattern to answer the research question. Since it is focused on the participants' experiences with having electronical assessment, some highlighted found, such as their feeling of doing eassessment and their supportive equipment to succeed in the online assessment. The next step is, underlining the specific words with certain sub-themes and generate the categories and writhe down a label through coding and the pick some examples of what students said on the interview.

\section{RESULTS}

From the interview conducted with five students of introduction to education course, it is found that eassessment is one of the interesting formative tests for them which is quite seldom applied in the other classes. It is common to have a paper-based test and undertaken in a classical environment. However, this situation sometimes does not support to create a comfortable condition to have an examination. "Sometimes, it is so crowded with 50 students in one class and I cannot concentrate on my test." (Student 2). In line with, another interviewee (student 1) revealed that having a test on midday with the air conditioner off is big trouble. These reasons then make them agree to try a new style of assessment. These opinions are only expressed in this sampling class, but also some research and survey done in the other locations found that more than $85 \%$ of students are more interested in online measurement than traditional assessment (Llamas-Nistal, et.al, 2013; Gilbert, Whitelock, and Gale, 2011; Donovan, Mader, and Shinsky, 2007).

\section{DISCUSSION}

In addition, the context of digital native coined by Prensky (2001) also suitable for this current issue of eassessment. As the research sampling was undergraduate students on semester 3 which are around 18-19 years old on average, it is open the opportunity to see this perspective from students is accustomed to digital devices. Prensky (2001) revealed that this generation engages with technologies for the whole life, such as for assisting them in running their activities on daily basis life, for entertaining, for education, etc. Therefore, this can be concluded that e-assessment is prone to be more convenient for them. As student 5 questioned, "why do we have to keep using paper when we have technologies around us?". Students 3 also supported this idea by saying that, "it is nice to do my assignment at home with my personal devices.". This feeling, according to Ridgway, McCusker, and Pead (2004), students are keen to have eassessment as it is like doing a simulation or playing a game but in a learning atmosphere. In addition, since the students are used to operating their own personal technological belonging, it will be easy to use on the situation of assessment (Eljinni, et. al., 2004).

Relating to this, student 4 expressed that psychologically he was more nervous while experiencing the paper-based test. It is because that he thought, he would be graded badly or would be failed. "Once I had a paper-based examination, one thing usually come out on my mind that the feeling I would not pass the test because I cannot write clearly, and the lecturers could not read my hand-writing.". This statement comes along with the feedback he got. "I sometimes cannot believe whether the lectures marking my assignment properly or not" (Student 4). This argument emerges since he found the fact that some of his friends got a better result than him even though he knows that his friend does not study well.

Speaking about feedback for students' eassessment, giving direct and immediate feedback will give an impact to improve students' learning performance and level (Gilbert, Whitelock, and Gale, 2011; Ridgway, McCusker and Pead, 2004). "I am satisfied with what I have done on e-assessment because the result has been released right after I finished the test (Student 4). Student 4 added that it usual that lecturers take times to grade our assessment and sometimes they do not give us the result, $\mathrm{s}$ so we do not know which parts they need to improve. This statement is associated with what Jordan and Mitchell (2009) relating to one of the benefits of eassessment, such as: 'This provides an opportunity for students to take immediate action to 'close the gap' 
between their current level of knowledge and a reference point and thus for the feedback to be effective".

From many studies, it is found that e-assessment is effective to be applied in higher education settings. However, in this research, there are some issues might appear during the implementation of e-assessment for formative test in introduction to education course as the type of test is multiple-choice questions, such as: since the test was not undertaken in the controllable class, it is easy for students to ask the answer to the other students. In addition, some students opened the book to find the answers. These prohibited activities decreased the validity of students' test result. Therefore, there should be some regulations to solve this problem so the e-assessment can apply optimally in line with the positive learning outcome.

\section{CONCLUSION}

Implementing e-assessment in formative tests in the introduction to education course has obtained a positive response from the students. It is because this type of test is unfamiliar as well as challenging but friendly for them as they can use their own technological devices to engage with this assessment. In addition, they feel comfortable while conducting electronical test because they do not have to attend class with a crowd of students in the small and hot classroom. Furthermore, getting quick feedback automatically from the teacher helps them to reflect on their achievement immediately.

\section{REFERENCES}

[1] Alruwais, N., Wills, G., \& Wald, M. (2018). Advantages and Challenges of Using E-assessment. International
Journal of Information and Education Technology, 8(1), 34-37.

[2] Biggs, J. (2003). Aligning teaching and assessment to curriculum objectives. Imaginative Curriculum Project, LTSN Generic Centre, 12.

[3] Depdiknas. (2003). Sistem pendidikan nasional. Jakarta (ID): Departemen Pendidikan Nasional

[4] Donovan, J., Mader, C., \& Shinsky, J. (2007). Online vs. traditional course evaluation formats: Student perceptions. Journal of Interactive Online Learning, 6(3), 158-180.

[5] Eljinini, M. A. H., Alsamarai, S., Hameed, S., \& Amawi, A. (2012). The Impact of E-assessments system on the success of the implementation process. International Journal of Modern Education and Computer Science, 4(11), 76 .

[6] Gilbert, L., Whitelock, D., \& Gale, V. (2011). Synthesis report on assessment and feedback with technology enhancement.

[7] Jordan, S., \& Mitchell, T. (2009). e-Assessment for learning? The potential of short-answer free-text questions with tailored feedback. British Journal of Educational Technology, 40(2), 371-385.

[8] Llamas-Nistal, M., Fernández-Iglesias, M. J., GonzálezTato, J., \& Mikic-Fonte, F. A. (2013). Blended eassessment: Migrating classical exams to the digital world. Computers \& Education, 62, 72-87.

[9] Prensky, M. (2001). Digital natives, digital immigrants part 1. On the horizon, 9(5), 1-6.

[10] Purwanto, Ngalim. (2012). Prinsip-Prinsip dan Teknik Evaluasi Pengajaran. Bandung: PT Remaja Rosdakarya.

[11] Ridgway, J., McCusker, S., \& Pead, D. (2004). Literature review of e-assessment. Bristol.

[12] Sitthisak, O., Gilbert, L., \& Davis, H. C. (2008). An evaluation of pedagogically informed parameterized questions for self-assessment. Learning, Media and Technology, 33(3), 235-248. 